\title{
The impact of tax rates on tax evasion: A macroeconomic study
}

\author{
Wajdi Affes ${ }^{a, 1}$ \\ ${ }^{a}$ Sfax University, Tunisia
}

\begin{abstract}
Research Question: What is the impact of high tax rates on the level of tax evasion in different economies? Motivation: after the occurrence of the famous panama papers and paradise papers scandal (Alstadsæte et al., 2019) and seeing that tax burden has been incessantly increased due to higher tax burden (Slemrod, 2017). Many research papers focused on the impact of tax evasion on the equilibrium of economies (Fisman \& Wei, 2004; Picur \& Riahi-Belkaoui, 2006). That's why we tried in our research paper to insist on the growth of the income tax rate as a principal determinant of tax evasion by emphasizing the importance of the economic characteristics of different countries. Idea: We examine the impact of tax burden on the level of tax evasion by analyzing the relationship between tax rates and tax evasion in the developed and emerging countries while taking on consideration their economic characteristics. Data: First of all, we analyze a sample of 143 countries where we focus on the cited relationship, then we divide this sample into 33 developed countries and 110 emerging countries. The collected data are related to the period preceding the publication date of the panama papers. Tools: We use a cross section analysis based on univariate and multivariate regression model applied for the whole sample and the two cited subsample groups. Findings: We find a positive and significant relationship between tax rates and tax evasion. This relationship no longer remains significant in the first group of the study which is composed by 33 developed countries however the second group composed by 110 emerging countries indicates that there is a positive and significant relationship between the two studied variables. Hence, in the following research we will strive for highlighting the main discriminate variables between both of the two cited samples. Contribution: The empirical findings have
\end{abstract}

${ }^{1}$ Corresponding author: Wajdi Affes, Faculty of Economics and Management of Sfax, Sfax University, Tunisia, Université de Route de l'Aéroport Km 0.5 BP 1169 .3029 Sfax Sfax, 3029, Tunisia, email address: affes.wajdi@hotmail.com 
economic and tax implications for governments and decision and policies makers especially in economies with high levels of tax evasion.

Keywords: income tax rates, tax evasion, economic characteristics, developed economies emerging economies.

JEL codes: H26, E62, E63

\section{Introduction}

Tax evasion is an important phenomenon that has always had a significant impact on global economies and levels of their development. Non-compliance with tax obligations has a very significant impact on government revenue (Picur \& RiahiBelkaoui, 2006). As a result, several studies and research works have tried to analyze and dissect the various factors that encourage such a phenomenon. In addition, global organizations such as the World Bank or the International Monetary Fund as well as professionals and researchers, such as Fred Celimene et al. (2014), have always tried to reflect by descriptive statistics and relevant analyses the substantial burden on governments due to tax evasion and the evolution of illegal parallel economies.

Obviously, various factors influence the level of tax evasion, including the level of sustainable development that has been addressed by Khlif et al. (2016).These authors have shown that the level of social and cultural development as well as the level of infrastructure development in the presence of a low level of corruption coincides with a low level of tax evasion. Others, such as Grant Richardson (2006), have highlighted the complexity of the rules of law as well as the demographic characteristics of different countries to explain the main determinants of tax evasion.

Based on previous research, we can say that studies of the determinants of tax evasion as well as the different factors that influence this phenomenon have focused on the social, cultural and institutional characteristics. Therefore, it is important to study the impact of economic factors, essentially the increasing tax rates on the degree of tax evasion in different economies. Indeed, the objective of our research work is to focus on the phenomenon of tax evasion in relation to the increase of corporate tax rates while taking into account the presence of different economic factors at the macroeconomic level. 
In this paper, we will try to operationalize what we have advanced through a crosssection analysis. The following of our paper is structured in four parts. In the first part we will try to outline the literature review to study the factors that may have a relationship with the phenomenon of tax evasion, namely the increase in corporate tax rates to reinforce our testing of the relationship predicted by the Laffer curve through the advancement of three hypotheses that consider the difference between the economic environments of the different countries in different economies. In the second part, we will present our research methodology where we will detail the path of sample selection and present variable used in our models. In the third part we will present our data processing and detail the result analysis by type of sample used during our empirical tests which allow us to find the detectable relationship between the degree of tax evasion and the variation in tax rates taking in account the different economic factors in a considerable number of developed as well as emerging and developing countries. Finally, we will present our conclusions.

\section{Literature review and hypotheses development}

Fraudulent tax evasion as an illegal attempt to minimize tax liabilities through fraudulent techniques to circumvent tax laws such as the fact of non-payment of taxes or the filing of income tax returns. understates the actual amount of taxes payable. Ttax evasion represents the illegal evasion of taxes by individuals, corporations and trusts. This type of Tax manipulation often leads taxpayers to deliberately distort the true state of their affairs to the tax authorities in order to reduce their tax debt through dishonest tax return filing, such as reporting less income, profits or earnings than amounts actually earned or as over-valuation of deductions.

At this level we can say that the reduction of tax liabilities in its two forms "tax evasion" and "tax avoidance" present a range of activity that reflects the intention to overturn a state's tax regime, but the difference is that tax evasion is illegal while tax avoidance is lawful and converges to the use of methods known as tax manipulation, which generally helps to manage the tax results down and subsequently reduce the amount of taxes to be paid.

In the same context, Feige and Cebula (2011) predict that tax evasion can defraud the government in terms of its tax revenues legally, this is will reduce its ability to provide public services, while increasing the heavy burden of the state debt. Noncompliance with tax obligations shifts real resources from honest taxpayers to dishonest ones and the tax burden of current generations to future generations.

These forms of inequality will cause citizen and corporate discontent with the government and further erode state fiscal revenues. Given these consequences, economists seek to estimate the scale, composition, growth and determinants of tax 
evasion in the hope of implementing public policies that can improve tax compliance. Regarding tax rates and referring to different countries in the world, tax regimes are mainly based on direct taxes and indirect taxes.

In the different countries of the world, tax regimes are essentially based on direct and indirect taxes. In our research work, we studied the role direct taxes can play in the phenomenon of tax evasion, particularly with respect to corporate tax. Given the importance of tax evasion, several research articles have focused on the factors that may influence this scourge, essentially tax rates which is a very important factor in the study of tax evasion. In this sense, Pommerehne and WeckHannemann (1996) have conducted an empirical analysis of citizens' noncompliance with taxes in twenty-five regions of the Swiss state based on the standard model of tax evasion.

In their model, they assessed tax evasion as the difference between income measures collected from tax reporting and those derived from national income accounts. They found a positive and significant relationship between the increase in marginal tax rates and tax evasion and a slightly significant negative relationship between tax evasion and the probability of detecting tax overruns reflected through the probability of audit. However, they did not find a significant relationship between tax penalties and the degree of tax evasion.

These authors have conducted their research to indicate that in the presence of a very precise degree of satisfaction of the taxpayers, the relation between the marginal tax rate and the tax evasion can change because the level of tax evasion decreases with the transparency and the possibility of public budget monitoring by taxpayers.

It is clear that the link between tax obligations and tax evasion presents a relevant relationship that needs to be investigated, introducing several factors, namely tax rates. Indeed, an increase in tax rates can lead to an increase in the level of tax evasion. Crane and Nourzad (1990) have made it clear that researchers in this field face problems in measuring the main variable especially tax evasion. They used three different measures, the most relevant of them is the difference between the amounts of declared taxes and the amount of taxes that must actually be declared. For this reason, they referred to data on the income of taxpayers in California collected through the "California amnesty data".

In their work, they introduced the probability of detection as a variable reflecting the level of audit and other demographic factors as a control variable. They found that when there is an increase in tax rates the degree of tax evasion increases. They also found that taxpayers with a high-income level tend to avoid paying their taxes. They also indicated that the study of the taxpayer's response to changes in tax rates may vary according to the change in the measure used to estimate the level of tax evasion. 
In the same context, Alstadsæter and Jacob (2013) find that the behavior of taxpayers (corporate entity) to avoid or reduce the amount of tax payable varies from one taxpayer to another. However, the increase in tax rates remains a remarkable factor having a significant impact on tax evasion. To confirm this, they examined the impact of fiscal incentives as well as raising awareness of the importance of compliance with tax obligations on the level of tax evasion. To this end, they oriented their concentration towards the degree of tax evasion of Swedish business owners based on panel-type administrative data that covers the period from 2006 to 2009 containing information on income, tax rates and other socioeconomic variables.

Moreover, they treated the impact of tax rates on the level of tax evasion through the amount of profits reclassified as dividends payable. In this context, they defined tax evasion as the difference between the amounts of dividends declared and the maximum allocation of profits allowed by the tax code. These authors have essentially relied on a model that treats the level of dividend allocation according to tax rates as well as the probability of detection and the indifference of taxpayers towards risk that is inspired by the tax evasion model of Allingham and Sandmo (1972). They found that between 2006 and 2009 about 5\% of Swedish companies submit a tax return that overstates the amount of profits allocated as profits to be distributed, hence a positive relationship between tax evasion and the increase in tax rates.

Their investigations end to finding a positive relationship in the Swedish context between tax evasion and the complexity of tax rules and that raising awareness of the importance of aligning with tax obligations reduces the number of false tax returns.

In order to better analyze the phenomenon of tax evasion and its relationship with tax rates, Chiarini et al. (2008) have studied the phenomenon of tax evasion over a long period of time. To this end, they used time series taken from the database of the Ministry of Finance of Italy representing the amounts of value-added tax (VAT) evaded by taxpayers between 1980 and 2004. They empirically studied the long-term characteristics of tax evasion and its relation to the heavy tax burden in the Italian context.

These authors indicate that the heavy burden of taxes payable is an important factor that influences the degree of tax evasion and the growth of underground economies in the majority of countries in the world, including Italy which in 2006 presented an amount of 200 billion euros as added value generated by the shadow economy. Based on the undeclared VAT amounts, these authors have estimated the size of the parallel markets and subsequently the degree of tax evasion because evading the VAT declaration corresponds to the non-declaration of an activity existing outside the territories of the formal economic. 
They found that Italian taxpayers adopt a tax evasion strategy that actually aims to maintain the gap between the effective tax rate and the apparent tax rate without exceeding a certain limit and that may have a relationship with the degree of risk aversion of taxpayers.

In addition, they found that long-term estimated parameters reflect a quick adjustment that seeks to regain balance, this contradicts the existence of a longterm strategy employed by taxpayers and confirms that in the short-run taxpayers will react quickly to any change using innovative techniques. This behavior is repetitive and passes from one generation to another in a remarkable way.

Finally, they found that, in the Italian context, there is no evidence of a vicious circle between tax evasion and tax pressure because these two variables always converge towards a stable equilibrium. In fact, these two variables are induced by a single stochastic trend. Most importantly, these authors have found that the average tax burden appears to be the main factor that drives the long-term trend of tax evasion. Based on the literature on the study of the relationship between tax rate and tax evasion or studies on the factors inciting tax evasion, we can present our first hypothesis:

\section{H1: there is a positive and significant relationship between tax rate and tax evasion}

Such a relationship is influenced by different economic factors that vary from one country to another, which is why identifying the difference between the economies of developed countries and emerging and developing countries remains important. In this context, Johannesen et al. (2016) used global data with information about 210,000 companies in 102 countries to examine whether the transfer of crossborder profits by multinational companies is less prevalent in developed countries. The originality of their work lies in proposing a new technique for studying income shifting in international markets. Most importantly, they found that the sensitivity of transferred benefits in order to benefit from tax incentives is negatively related to the level of economic and institutional development. This may explain why many developing countries opt for low corporate tax rates, despite urgent income needs and severe constraints on the use of other tax bases. Based on what has been advanced, it is necessary to add two other research hypotheses that would lead to distinguishing different economic environments.

\section{H2: there is a positive and significant relationship between tax rate and tax evasion in developed countries}

H3: there is a positive and significant relationship between tax rate and tax evasion in emerging and developing countries 


\section{Research methodology}

\subsection{Sample selection}

Our study is essentially based on data that has been collected from the Global Competitiveness Report (GCR) which is published annually by the World Economic Forum Since 2004, this report has been based on a Global Competitiveness Index (GCI) (Sala-i-Martin et al., 2004). This index assesses the ability of countries to respond to citizens' needs which is directly related to governments' use of their resources. It takes into consideration several factors or sub-indices having an impact on the economies of the different countries. To identify the values that must be attributed to the main variable, which is tax evasion, we referred to the data and estimates of parallel or underground economies made by Friedrich Schneider et al. (2010).

In the present work, we used the average size of the parallel markets of each country among the 162 countries that were estimated over a period spanning 1999 and 2007 by Schneider et al. (2010). We then eliminated nine countries representing the tax havens that were indicated by Jaafar and Thornton (2015) and which coincide with the countries treated by Schneider et al. (2010), namely Bahamas, Bahrain, Belize, Cyprus, Liberia, Maldives, Malta, Mauritius and Panama. After the elimination of tax havens countries, we obtained a sample of 153 countries which was further reduced to143 countries.

The selection of the final sample is illustrated in the following table:

Table 1. The process of sample selection

\begin{tabular}{lc}
\hline Initial sample & 162 countries treated by Schneider et al. (2010) \\
Tax havens that coincide with our & (9) countries selected refe rring to Aziz Jaafar \& \\
sample & John THornton (2015): Bahamas, Bahrain, \\
& Belize, Cyprus, Liberia, Maldives, Malta, \\
& Maurituis, Panama \\
Countries presenting deviant & (5) Countries: UAE, Vietnam, Yemen, Zambia, \\
observations & New Zealand \\
$\begin{array}{l}\text { Countries presentingobservation with } \\
\text { tax rate Greater than 35\% }\end{array}$ & (3) Countries: USA, Suriname, Chad \\
$\begin{array}{l}\text { Countries presenting heteroscedastic } \\
\text { observation problem }\end{array}$ & (2) Countries: Georgia, Bolivia \\
Final sample & \\
\hline
\end{tabular}




\subsection{Presentation and Measurement of Variables}

\subsubsection{The dependent variable (TEV)}

The dependent variable which is tax evasion "TEV" is reflected in the estimation of the size of parallel economies (as a percentage of GDP) of 162 countries presenting the developed countries, the countries of Eastern Europe, countries of central Asia, high-income countries members of Organisation for Economic Co-operation and Development (OECD) and many more (Schneider et al., 2010).

Buehn and Schneider (2007) found that the shadow or underground economy is an excellent proxy for estimating the value of tax evasion. Schneider et al. (2010) based their work on the statistical theory of unobserved variables to achieve a reliable estimate of the size of underground economies. According to these authors such an estimate remains difficult and they provided the following: "Unfortunately, it is very difficult to get accurate information about shadow economy activities on the goods and labour market, because all individuals engaged in these activities do not wish to be identified. Hence, doing research in this area can be considered as a scientific passion for knowing the unknown".

This method considers several causes and multiple indicators of the phenomenon to be measured. To be more precise the authors used the multiple indicators multiple causes (MIMIC) model; a structural equation model (SEM) containing a single latent variable that is tax evasion. In order to measure the relationship between the observed variables and the non-observed variable, the authors used the structural equation model (SEM) to compare the covariance between these variables across the covariance matrix.

It is worth noting that the pioneers of this approach are Frey and Weck-Hannemann (1984). Subsequently, to calculate the size of parallel economies, the authors converted the indices obtained through the MIMIC model to reflect the reality of things more reliably. They adopted the percentage of GDP as a measure of these parallel economies. To this end, they used a procedure called calibration or "benchmarking" referring to Dell'Anno (2007) and Dell'Anno and Solomon (2008).

In our work, we will use the average size of parallel markets estimated between 1999 and 2007 to quantify the intensity of tax evasion in different countries. Based on previous works, we can say that an increase or a decrease in tax evasion in the economies of different countries cannot happen overnight. Such an interpretation was inspired from analyzing the descriptive statistics performed by Elgin et al. (2012). At the level of the multivariate analysis, we compared the averages of tax evasion with the corporate tax rates of the different countries that were updated to 2015.

Vol. 19, No. 2 


\subsubsection{The independent variable (TR) and control variables}

In our research work we limited ourselves to the variable (TR) which will allow us to test the assumption that "rates cut down the totals". In order to test the association between the tax rate and the degree of tax evasion, we collected the tax rates of each country referring to the corporate tax rates provided by the web site of KPMG in 2015.

It should be noted that KPMG only presents the data of 148 countries, for this we were obliged to refer to data provided by the World Bank to supplement the rates of the 14 missing countries in order to have the corporate tax rates of 162 countries provided in the article of Schneider et al. (2010). Indeed, these rates are measured as the percentage of revenues earned by different companies in different countries of the world. The corporate tax rates for the 162 countries are presented in Appendix1.

Regarding the control variables we relied on the data collected from the GCR. In this sense it should be noted that we used the most relevant indicators that were used for the calculation of the GCI as well as those used by previous research. These include the size of the market, the degree of investor protection, strength of investor protection, the legal right index and the strength of auditing and reporting standards.

We also took into account the most problematic factors that can impact the productivity of countries while focusing on two factors that are corruption and bureaucracy. The detail of these control variables is presented in Appendix 2.

\section{Data processing and research findings}

In this section we will present how via the implementation of a univariate and multivariate analysis we tested for the relationship between tax rate and tax evasion using simple and partial correlation while focusing on a multivariate ordinary least squares (OLS) model. In our analysis we will focus on the difference between results found at the level of our two subsample which reflect the remarkable difference between developed and emerging economies.

\subsection{Analysis and interpretation of results of the total sample (143 countries)}

Here, we were interested in studying the phenomenon of tax evasion assuming that there is an interesting link between this scourge and the level of tax rates. We emphasized this link trying to consider the effect of the different economic factors.

For this reason and after carrying out the preliminary tests and the verification of the conditions necessary for the realization of the data analysis, we chose the 
multiple linear regression which aims at explaining the variation of a phenomenon by one or more other phenomena. In what follows, we will present the descriptive statistics, the univariate analysis and the multivariate analysis for the 143 countries.

\subsubsection{Descriptive statistics}

The main characteristics of the variables used to obtain the linear regression are presented based on the table of the descriptive statistics.

Table 2. Descriptive statistics of the variables of 143 countries

\begin{tabular}{lcccccccc}
\hline & TEV & TR & COR & BUR & LRI & MSS & IP & ARS \\
\hline \multirow{2}{*}{$\mathrm{N} \quad$ Valid } & 143 & 143 & 123 & 123 & 123 & 123 & 123 & 123 \\
\multicolumn{1}{c}{ missing } & 0 & 0 & 20 & 20 & 20 & 20 & 20 & 20 \\
\hline Average & 32.838 & 24.476 & 0.601 & 0.780 & 5.902 & 3.878 & 5.365 & 4.631 \\
Median & 33.600 & 25.000 & 1.000 & 1.000 & 6.000 & 3.796 & 5.300 & 4.600 \\
Mode & 34.90 & 30.00 & 1.00 & 1.00 & 3.00 & 1.296 & 5.00 & 2.204 \\
Standard & 12.096 & 6.677 & 0.491 & 0.415 & 2.323 & 1.134 & 1.576 & 0.881 \\
deviation & 146.324 & 44.592 & 0.242 & 0.173 & 5.400 & 1.287 & 2.486 & 0.777 \\
Variance & 8.50 & 10.00 & 0.00 & 0.00 & 1.00 & 1.296 & 1.70 & 2.204 \\
Minimum & 61.80 & 35.00 & 1.00 & 1.00 & 10.00 & 6.861 & 9.30 & 6.701 \\
\hline Maximum & & & & & & & &
\end{tabular}

This table shows that our sample consists of 143 countries including 20 countries whose information regarding control variables is not available. It also shows that our dependent variable (TEV) which is the level of tax evasion has an average of 32.8385 and a mode (the most frequent value) of 34.90 with a maximum value of 61.8 corresponding to "Zimbabwe", which is an emerging country, and a minimum value equal to 8.5 corresponding to "Switzerland", which is a developed country.

Regarding the independent variable (TR), it has an average of 24.4764 with a mode of 30 , a maximum value of 35 and a minimum value equal to 10 . Regarding the control variables, we note that corruption (COR) has an average of 0.6016 and bureaucracy (BUR) has an average of 0.7805 . The legal protection of rights index (LRI) has an average of 5.9024 with a value that varies between 1 and 10, the market size (MSS) has an average of 3.8789 with a minimum and a maximum size of 1.2969 and 6.8617, respectively. The degree of Investor protection (IP) has an average of 5.3650 and varies between 1.7 and 9.30. Finally, the quality of auditing and reporting standards (ARS) has an average of 4.6311 with a value that varies between a minimum of 2.2040 and a maximum of 6.7014 .

For corruption and bureaucracy, the averages shown do not reflect the reality because these two variables were measured by the use of a Boolean variable $[0,1]$ 
where the variable equals 1 if corruption or Bureaucracy is one of the top five most problematic factors predicted by the GCR. It should be noted that "Denmark", "Japan", "New Zealand" and "Switzerland" have the lowest levels of corruption, while "Burundi" and "Guyana" present the most corrupt countries. Regarding bureaucracy, we note that "Gambia" and "Singapore" present the countries with the lowest levels of bureaucracy, however "Costa Rica" presents the highest level of bureaucracy.

\subsubsection{Univariate analysis}

Before presenting the multivariate regression analysis, we discuss the correlation between the variables to be studied which presents the conceptual basis of the regression. In fact, the Pearson correlation is a statistic used to measure the importance of the relationship between the different metric variables. At this level we present our correlation matrix (Table 3) with 143 observations for the dependent and independent variable as well as 123 observations for the control variables due to missing data from 20 countries whose data were unavailable. It should be noted that in our analysis using Statistical Package for the Social Sciences (SPSS) and even for subsequent analyses during sample division all incomplete observations were excluded.

Table 3. The Pearson Correlations matrix of 143 Countries

\begin{tabular}{lcccccccc} 
& TEV & TR & COR & BUR & LRI & MSS & IP & ARS \\
\hline TEV & 1 & $0.202^{*}$ & $0.495^{* *}$ & -0.115 & -0.113 & $-0.446^{* *}$ & $-0.235^{* *}$ & $-0.516^{* *}$ \\
TR & $0.202^{*}$ & 1 & 0.009 & -0.164 & -0.168 & 0.087 & $-0.248^{* *}$ & -0.050 \\
COR & $0.495^{* *}$ & 0.009 & 1 & $-0.231^{*}$ & -0.013 & $-0.239^{* *}$ & -0.152 & $-0.469^{* *}$ \\
BUR & -0.115 & -0.164 & $-0.231^{*}$ & 1 & 0.139 & $0.253^{* *}$ & 0.118 & $0.253^{* *}$ \\
LRI & -0.113 & -0.168 & -0.013 & 0.139 & 1 & 0.126 & $0.421^{* *}$ & $0.349^{* *}$ \\
MSS & $-0.446^{* *}$ & 0.087 & $-0.239^{* *}$ & $0.253^{* *}$ & 0.126 & 1 & $0.326^{* *}$ & $0.380^{* *}$ \\
IP & $-0.235^{* *}$ & $-0.248^{* *}$ & -0.152 & 0.118 & $0.421^{* *}$ & $0.326^{* *}$ & 1 & $0.396^{* *}$ \\
ARS & $-0.516^{* *}$ & -0.050 & $-0.469^{* *}$ & $0.253^{* *}$ & $0.349^{* *}$ & $0.380^{* *}$ & $0.396^{* *}$ & 1 \\
\hline
\end{tabular}

*. The correlation is significant at 0.05 level (bilateral).

**. The correlation is significant at 0.01 level (bilateral).

Note: the number of observations for the dependent and independent variable corresponds to 143 countries and that for control variables corresponds to 123 countries.

In fact, the Pearson correlation coefficient is a measure of association that makes it possible to know whether two variables vary in a similar way or not. In the course of our research work, we targeted from the beginning the potential relationship between the level of tax evasion and the variation in tax rates. Indeed, based on the results found in the Pearson correlation matrix, we find that the level of tax 
evasion, already measured by reference to black or underground markets, shows a positive and significant relationship at 5\% level with tax rates applied in a mandatory manner according to the tax laws of different countries. This relationship has already been envisaged in the literature on tax evasion.

In addition, we note that our dependent variable tax evasion, is positively and significantly correlated at the $1 \%$ level with corruption, a negative and significant correlation at $5 \%$ level with market size, the degree of protection of investors and the quality of reporting and auditing standards.

Regarding the independent variable (TR), we note that it has a negative and significant correlation with the level of protection of investors at the 5\% level. Furthermore, we note that bureaucracy has a negative and significant correlation at the 5\% level with corruption in these countries. The market size has a negative and significant correlation at the $1 \%$ level with the degree of corruption but a positive and significant correlation at the $1 \%$ level with bureaucracy. Investor protection is also positively and significantly correlated at the $1 \%$ level with the level of legal protection of rights and market size.

Finally, we note that the quality of reporting and auditing standards is negatively and significantly correlated at the $1 \%$ level with corruption but positively and significantly correlated at the $1 \%$ level with bureaucracy, the level of legal protection of rights, market size and level of investor protection. Moreover, we used the partial correlation matrix to verify the significance of the relationship between the dependent variable and the independent variable, taking into consideration the impact of the control variables (Table 4).

Table 4. Partial Correlation Matrix for 143 Countries

\begin{tabular}{lllcc}
\hline Control variables & & TEV & TR \\
\hline & & Correlation & 1.000 & 0.257 \\
& TEV & Significance (bilateral) & - & 0.005 \\
COR,BUR, LRI, & & ddl & 0 & 115 \\
\cline { 2 - 5 } MSS, IP and ARS & & Correlation & 0.257 & 1.000 \\
& \multirow{2}{*}{ TR } & Significance (bilateral) & 0.005 & - \\
& & ddl & 115 & 0 \\
\hline
\end{tabular}

These results indicate that even when the relationship between tax evasion and the tax rates of different countries is controlled by the use of 6 control variables, we always get a positive and significant correlation at the 5\% level which presents an evolution from 20.2 to $25.7 \%$. At this point, we found a relationship between the variable to be explained and the explanatory variable but we could not determine the meaning of this relationship. 


\subsubsection{The multivariate analysis}

At this level, we make use of the multiple linear regression which will enable us to explain our dependent variable (TEV) by the quantitative independent variable (TR) taking into consideration the effect of the six control variables which are COR, BUR, LRI, MSS, IP and ARS. The results obtained using the SPSS software are as follows:

The summary data of the model are presented in Table 5.

Table 5. The summary table of the model for the 143 countries

\begin{tabular}{cccc}
\hline $\mathbf{R}$ & R-two & R-two ajusted & Standard error of the estimate \\
\hline 0.677 & 0.459 & 0.426 & 9.42716
\end{tabular}

As can be seen from this table, the multiple correlation (R) is equal to 0.677 . This correlation reflects the degree of dependence between the dependent and the independent variables under the control of the six control variables. It is worth noting that if we have a multiple correlation coefficient that exceeds 0.8 then we have a strong dependency between the variables being analyzed.

Indeed, as we have an $\mathrm{R}<0.8$, we can proceed to the analysis of the multiple coefficient of determination R-two which is equal to 0.459 . This indicates that $45.9 \%$ of the variance of the tax evasion (TEV) is explained by the independent variable taking account of the effect of control variables. This value of $R^{2}$ can be biased, for that we resorted to the real effect that is given by adjusted $\mathrm{R}^{2}$ which has a value of 0.426 . These coefficients provide important information on the degree of explanation provided by the model; however, and in order to evaluate the overall explanatory power of the model we will refer to the Fisher test which is presented in table 6.

Table 6. ANOVA table for the 143 countries

\begin{tabular}{lccccc}
\hline & the sum of squares & dd & mean squares & D & Sig. \\
\hline Regression & 8661.897 & 7 & 1237.414 & 13.924 & 0.000 \\
Residue & 10220.213 & 115 & 88.871 & - & - \\
Total & 18882.110 & 122 & - & - & - \\
\hline
\end{tabular}

As can be seen from this table, Fisher $\mathrm{F}$ is equal to 13.924. The null hypothesis of Fisher's test is as follows: $\mathrm{H} 0=$ no variable explains the dependent variable (TEV). As can be seen from the ANOVA table we find that we have a significance that is $0.00<0.05$ so the risk of rejecting $\mathrm{H} 0$ is low. Thus, we can reject H0. This indicates that there is at least one variable that explains the dependent variable and therefore our model is globally significant. Then and for the presentation of our model we focus on the results which appear at the level of the following table of coefficients: 
Table 7. Table of coefficients for 143 countries

\begin{tabular}{lccccc}
\hline \multicolumn{7}{c}{$\begin{array}{c}\text { Non-standardised } \\
\text { coefficients }\end{array}$} & $\begin{array}{c}\text { standardised } \\
\text { coefficients }\end{array}$ & & \\
\hline (Constant) & $\mathrm{A}$ & Standard error & Beta & $\mathrm{t}$ & Sig. \\
TR & 44.883 & 7.224 & & 6.213 & 0.000 \\
COR & 0.401 & 0.141 & 0.210 & 2.851 & 0.005 \\
BUR & 7.949 & 2.024 & 0.314 & 3.927 & 0.000 \\
LRI & 4.252 & 2.220 & 0.142 & 1.915 & 0.058 \\
MSS & 0.141 & 0.425 & 0.026 & 0.332 & 0.741 \\
IP & -3.679 & 0.867 & -0.335 & -4.244 & 0.000 \\
ARS & 0.519 & 0.662 & 0.066 & 0.783 & 0.435 \\
\hline
\end{tabular}

The model studying the relationship between the level of tax evasion and tax rates considering the effect of control variables can be developed based on table 8. It can be summarized through the use of a model summary diagram which is given as follows:

\section{$T E V=44.883+0.401 T R+7.949 C O R+4.252 B U R+0.141 L R I-3.679 M S S+0.519 I P-$ $4.264 A R S+\varepsilon$}

We notice that the independent variable (TR) has a Student t-test equal to 2.851> 1.96 and a p-value of $0.5 \%<5 \%$. This result allows us to reject the null hypothesis of the student test which is as follows: $\mathrm{HO}=$ "TR" has no effect on (TEV). Therefore, we can conclude that (TR) has a positive effect on (TEV) and as these two variables have a significant correlation, we can confirm our hypothesis $\mathrm{H} 1$ which predicts that there is a positive and significant relationship between tax rate and the degree of tax evasion.

Accordingly, we can confirm that in countries with relatively high tax rates we can find a tendency to avoid paying taxes or a tendency to move towards black markets in order to escape heavy burden of taxes to be borne by businesses and taxpayers, which explains the growth in the level of tax evasion. This result is in line with the results in the literature and converges with the principle inspired by the Laffer curve which predicts that "rates cut down the totals".

Finding such a positive and significant relationship between tax rates and the level of tax evasion leads us to further analyze this phenomenon in the different countries of our sample. Indeed, and to test hypotheses $\mathrm{H} 2$ and $\mathrm{H} 3$, we had to divide our sample of 143 countries into two sub-groups inspired from the IMF country classification. This classification enables us to test the relationship between tax rates and the level of tax evasion in developed countries as well as emerging and developing countries. 


\subsection{Analysis and interpretation of results of 33 developed countries subsample}

By dividing the sample of 143 countries, we obtain the first group of 33 developed countries. In fact, to test the relationship between tax evasion and tax rates in these countries, we used the SPSS software results.

\subsubsection{Descriptive statistics of developed countries subsample}

First, we will focus on the characteristics of the variables used to study the relationship between tax rates and the level of tax evasion in developed countries. The descriptive statistics of this group of countries are given in Table 8:

Table 8. Descriptive Statistics of Variables of 33 Developed Countries

\begin{tabular}{lcccccccc}
\hline & TEV & TR & COR & BUR & LRI & MSS & IP & ARS \\
\hline N Valid & 33 & 33 & 32 & 32 & 32 & 32 & 32 & 32 \\
\multicolumn{1}{c}{ Missing } & 0 & 0 & 1 & 1 & 1 & 1 & 1 & 1 \\
\hline Average & 18.842 & 23.008 & 0.187 & 0.937 & 7.031 & 4.584 & 6.196 & 5.436 \\
Median & 17.700 & 22.000 & 0.000 & 1.000 & 7.000 & 4.588 & 6.000 & 5.527 \\
Mode & 16.00 & 20.00 & 0.00 & 1.00 & 7.00 & 2.441 & 5.70 & 4.188 \\
Standard & 6.495 & 6.214 & 0.396 & 0.245 & 2.071 & 0.915 & 1.455 & 0.643 \\
deviation & & & & & & & & \\
Variance & 42.189 & 38.614 & 0.157 & 0.060 & 4.289 & 0.839 & 2.118 & 0.414 \\
Minimum & 8.50 & 12.00 & 0.00 & 0.00 & 3.00 & 2.441 & 3.00 & 4.188 \\
Maximum & 32.00 & 33.99 & 1.00 & 1.00 & 10.00 & 6.142 & 9.30 & 6.424 \\
\hline
\end{tabular}

As can be seen from this table our sample consists of 33 developed countries including one country whose information regarding control variables could not be obtained. The dependent variable (TEV) has an average of 18.8424 and a mode of 16 with a maximum value of 32 corresponding to "Lithuania" and a minimum value equal to 8.5 corresponding to "Switzerland". The independent variable (TR) has an average of 23.0082 with a mode equal to 20, a maximum value of 33.99 and a minimum value equal to 12 . Regarding control variables, we note that corruption (COR) has an average of 0.1875. Bureaucracy (BUR) has an average of 0.9375 but it must be reminded that these two variables were measured by converting them to a Boolean variable $[1,0]$. The legal protection of rights index (LRI) has an average of 7.0313. Thus, it presents as maximum value equal to 10 and a minimum value of 3. The market size (MSS) has an average of 4.5841 and a value that ranges from 2.441 to 6.142 .

The investor protection level (IP) has an average of 6.196 with a minimum of 3 and a maximum of 9.3. Finally, the quality of reporting and auditing standards (ARS) 
presents an average of 5.436 and has a value that varies between 4.188and 6.424. Having had a clear idea about the values and descriptive statistics of the different factors that can affect the phenomenon of tax evasion in developed countries, we proceed to the following level of univariate analysis based on the correlation matrix and then to the multivariate analysis.

\subsubsection{The univariate analysis of developed countries subsample}

For more precision and in order to test the correlation between the two main variables that are the subject of our research work, we relied on the partial correlation matrix which takes account of the effect of the 6 control variables. The SPSS software provided the results displayed in (Table 9).

Table 9. The partial correlation matrix for the 33 developed countries

\begin{tabular}{lllcc}
\hline Control variables & & TEV & TR \\
\cline { 2 - 5 } & & Correlation & 1.000 & -0.028 \\
& TEV & Significance (bilaterale) & - & 0.893 \\
COR,BUR, LRI, & & ddl & 0 & 24 \\
\cline { 2 - 5 } MSS, IP and ARS & & Correlation & -0.028 & 1.000 \\
& TR & Significance (bilateral) & 0.893 & - \\
& & ddl & 24 & 0 \\
\hline
\end{tabular}

This partial correlation table shows that there is no correlation between the level of tax evasion and the value of tax rates in developed countries even after considering the effect of the control variables which reflect the impact of the characteristics of the economic environment on such a relationship. Despite the failure to obtain a significant correlation between the level of tax evasion and the variation of tax rates in developed countries, we referred to the linear regression based on the OLS method in order to develop the representative model of the relationship between the different variables used in our research. To this end, we turned to the multivariate analysis presented in the following section.

\subsubsection{The multivariate analysis of developed countries subsample}

First, we will discuss the variables used to perform the data analysis with respect to the developed countries. Subsequently, to verify the degree of explanation of the information provided by the multiple linear regression analysis, we used the summary table of the model (table10):

Table 10. Summary table of the model for the 33 developed countries

\begin{tabular}{cccc}
\hline $\mathbf{R}$ & R-deux & R-two ajusted & Standard error of the estimate \\
\hline 0.693 & 0.481 & 0.330 & 5.317 \\
\hline
\end{tabular}

Vol. 19, No. 2 
As can be seen from this table, the multiple correlation $\mathrm{R}$ is equal to 0.693 . This correlation reflects the degree of dependence between the dependent variable and the other variables of the model. With $\mathrm{R}<0.8$, we proceed to the analysis of the multiple coefficients of determination $\mathrm{R}^{2}$ which is equal to 0.481 . This coefficient indicates that $48.1 \%$ of the variance of the tax evasion is explained by the other variables. For more precision and in order to get closer to the actual effects between the variables, we notice that the $\mathrm{R}^{2}$ adjusted is equal to 0.330 . These coefficients show the degree of explanation provided by the model. To evaluate the overall significance of the model we will refer to Fisher's test which is presented in the following ANOVA table:

Table 11. ANOVA table for the 33 developed countries

\begin{tabular}{cccccc}
\hline & Sum of the squares & ddl & mean squares & D & Sig. \\
\hline Regression & 628.703 & 7 & 89.815 & 3.177 & 0.016 \\
Residue & 678.555 & 24 & 28.273 & - & - \\
Total & 1307.259 & 31 & - & - & - \\
\hline
\end{tabular}

As can be seen from the table, the F of Fisher is equal to 3.177 and the p-value is less than 0.05 . This ensures that there is at least one variable that can explain the phenomenon of tax evasion and shows the overall significance of the model studying the relationship of tax evasion with tax rates in developed countries taking account of the effect of the economic characteristics of these countries. After testing the global characteristics of the model, we used the partial analysis to elaborate our model and to draw the appropriate conclusions about the relation between tax evasion and tax rates in developed countries.

Table 12. Table of coefficients for the 33 developed countries

\begin{tabular}{|c|c|c|c|c|c|}
\hline & \multicolumn{2}{|c|}{$\begin{array}{c}\text { Unstandardized } \\
\text { coefficients }\end{array}$} & \multirow{2}{*}{$\begin{array}{c}\begin{array}{c}\text { Standardized } \\
\text { coefficients }\end{array} \\
\text { Bêta }\end{array}$} & \multirow[b]{2}{*}{$\mathrm{t}$} & \multirow[b]{2}{*}{ Sig. } \\
\hline & A & $\begin{array}{c}\text { Standard } \\
\text { error }\end{array}$ & & & \\
\hline (Constant) & 49.230 & 13.711 & & 3.590 & 0.001 \\
\hline TR & -0.029 & 0.213 & -0.027 & -0.136 & 0.893 \\
\hline COR & 2.266 & 3.010 & 0.138 & 0.753 & 0.459 \\
\hline BUR & 1.160 & 4.097 & 0.044 & 0.283 & 0.780 \\
\hline LRI & -0.406 & 0.576 & -0.129 & -0.704 & 0.488 \\
\hline MSS & -1.270 & 1.295 & -0.179 & -0.980 & 0.337 \\
\hline IP & 1.012 & 0.748 & 0.227 & 1.353 & 0.189 \\
\hline ARS & -5.264 & 1.865 & -0.521 & -2.823 & 0.009 \\
\hline
\end{tabular}


Based on these findings, we can present the following model:

$T E V=49.230-0.029 T R+2.266 C O R+1.160 B U R-0.406 L R I-1.270 M S S+1.012 I P-$ $5.264 A R S+\varepsilon$

Based on this model we find that the variable (TR) has a negative sign indicating that if tax rates increase then the level of tax evasion will decrease in developed countries. In addition, this explanatory variable has a p-value of 0.893 , which is well above 0.05, and has a t Student with an absolute value of $0.13<1.96$ (or P-value <0.05). Thus, the null hypothesis of the Student test is accepted: $\mathrm{H} 0 \mathrm{=}$ TR has no effect on TEV. In the same context, and since we did not find a significant correlation between the variable to be explained and the explanatory variable, we can reject our second hypothesis $\mathrm{H} 2$ that predicts that there is a positive and significant relationship between the tax rate and the degree of tax evasion in developed countries

This result shows that despite finding a meaningful relationship in our sample of 143 countries, we did not find the same result with regards to developed countries. This can be explained by the level of development of the economic environment in which the tax system of these countries operates.

Moreover, the non-existence of a relationship between tax rates and the level of tax evasion in developed countries can be explained by the respect of the taxpayers of these countries for ethical principles. We believe that these results remain reasonable because the taxpayers of the developed countries declare themselves aware of the importance of taxes in the funding of public projects and especially of sharing co-citizenship values. In the same vein and in the light of these results, we expect that the implementation strategies encouraging compliance of taxpayers with taxes and the use of information technologies in developed countries can be very important factors in reducing the level of tax evasion and eliminating underground markets which usually emerge from high tax rates.

Finally, in view of the fact that we rejected the second hypothesis, it must be said that in the developed countries there are other factors that can have a remarkable effect on the phenomenon of tax evasion. To be more explicit, we can say that the level of confidence in governments and tax administrations as well as the level of trust shared among different stakeholders are considered to be the most influential factors in reducing the level of tax evasion in developed economies.

These factors have been addressed by Wintrobe and Gërxhani (2004) who have argued that the standard theory of tax evasion cannot explain adequately the difference between different countries with respect to the phenomenon of tax evasion. These authors have tried to complement the contributions of public choice theory, which describes the role of the government and the behavior of voters, politicians and public officials, based on an overview of the institutional economy. 
In fact, they support the idea that the level of tax evasion is higher in some countries (e.g., countries in transition) than in others (e.g., institutionally advanced countries). For this reason, they explain the difference between the developed and developing countries by the level of confidence of taxpayers in government as well as the level of confidence in the willingness of others to pay taxes. They elucidate that developed countries have a lower level of tax evasion compared to countries in transition and developing countries by the fact that taxpayers in developed countries generally trust governments that have been elected democratically. As a conclusion, we can say that the institutional factors, the quality of the applied standards as well as the level of consciousness of the taxpayers can influence the degree of tax evasion in the developed countries. However, the interest to know the factors that significantly impact the level of tax evasion in emerging countries urges us to focus on the second group of our sample, which consists of 110 emerging and developing countries.

\subsection{Analysis and interpretation of results of 110 emerging and developing countries subsample}

After analyzing the relationship of tax rate and tax evasion in the developed countries we will focus on the case of emerging countries which are presented in our research paper by 110 countries.

\subsubsection{Descriptive statistics of emerging countries subsample}

Table 13 shows the descriptive statistics of the different variables used in the study of the relationship between increasing tax rates and the degree of tax evasion in emerging and developing countries.

Table 13. Table of Descriptive Statistics of the variables of 110 Emerging and Developing Countries

\begin{tabular}{lcccccccc}
\hline & TEV & TR & COR & BUR & LRI & MSS & IP & ARS \\
\hline \multirow{2}{*}{$\begin{array}{l}\text { Valid } \\
\text { missing }\end{array}$} & 110 & 110 & 91 & 91 & 91 & 91 & 91 & 91 \\
\hline Average & 37.037 & 24.916 & 0.747 & 0.725 & 5.505 & 3.630 & 5.072 & 4.347 \\
Median & 36.950 & 25.000 & 1.000 & 1.000 & 6.000 & 3.582 & 5.3000 & 4.333 \\
Mode & 34.90 & 30.00 & 1.00 & 1.00 & 3.00 & 1.296 & 6.70 & 2.204 \\
Standard & 10.056 & 6.775 & 0.436 & 0.448 & 2.287 & 1.102 & 1.51914 & 0.773 \\
deviation & & & & & & & \\
Variance & 101.141 & 45.907 & 0.191 & 0.201 & 5.231 & 1.216 & 2.308 & 0.599 \\
Minimum & 12.70 & 10.00 & 0.00 & 0.00 & 1.00 & 1.296 & 1.70 & 2.204 \\
Maximum & 61.80 & 35.00 & 1.00 & 1.00 & 10.00 & 6.861 & 8.70 & 6.7014 \\
\hline
\end{tabular}


As can be seen from this table, our sample is composed of 110 emerging and developing countries including 19 countries whose information regarding the control variables could not be obtained. As a reminder we have indicated that in terms of data analysis we opted for the option of eliminating missing observations.

The dependent variable (TEV), has an average of 37.0373 which is remarkably higher than that of developed countries which have an average of 18.8424 and a mode of 34.90 with a maximum value equal to 61.80 corresponding to "Zimbabwe" and a minimum value equal to 12.7 corresponding to "China". Regarding the independent variable "TR", we find that it has an average of 24.9169 with a mode of 30 , a maximum value of 35 and a minimum value equal to 10 .

For the control variables, we note that corruption (COR) has an average of 0.747 which is higher than the level of corruption in developed countries (0.187), bureaucracy (BUR) has an average of 0.725 which is lower than that in developed countries (0.937). The legal protection index (LRI), presents a value that varies between 1 and 10 and has an average of 5.505 which is lower than that in developed countries (7.031). The market size (MSS) has a minimum value of 1.296 and a maximum value of 6.861 . It has an average of 3.631 which is smaller than the size of the markets in the developed countries (4.584) and the investor protection degree (IP) has an average of 5.0725 which is lower than that of developed countries (6.196). Finally, we notice that the variable reflecting the quality of reporting and auditing standards (ARS) has a minimum and a maximum value of respectively 2.204 and 6.701 with an average of 4.347 which is lower than that in developed countries (5.436).

Indeed, for the control variables, we notice that the factors representing the economic environment in the emerging and developing countries are less sophisticated compared to developed countries, which is quite logical. We can therefore say that the evolution and development are factors that can create a prosperous working and commercial environment that significantly influence the size of parallel markets and consequently the level of tax evasion. This is confirmed by the level of tax evasion in emerging and developing countries, which is twice the value of tax evasion in developed countries.

After having interpreted the descriptive statistics of the economic factors of emerging and developing countries, we turn to the interpretation of the relation between the phenomenon of tax evasion and the legal tax rates applied in these countries. For this we need to interpret the correlation between the different variables and to analyze data by the use of a multiple linear regression model.

\subsubsection{The univariate analysis of emerging countries subsample}

At this stage, we need to use the partial correlation matrix to deduce the possible relations existing between the phenomenon of tax evasion and the other studied 
variables, particularly for emerging and developing countries. Based on Table 14, we note that the correlation between tax rates and tax evasion leads to affirm the relationship between them taking into consideration the impact of the characteristics of the economic environment.

Table 14. The Partial Correlation Matrix for the 110 Emerging and Developing Countries

\begin{tabular}{lllcc}
\hline Control variables & & TEV & TR \\
\hline & & Correlation & 1.000 & 0.275 \\
& TEV & Significance (bilateral) & - & 0.011 \\
COR,BUR, LRI , & & ddl & 0 & 83 \\
\cline { 2 - 5 } MSS , IP \& ARS & Correlation & 0.275 & 1.000 \\
& TR & Significance (bilateral) & 0.011 & - \\
& & ddl & 83 & 0 \\
\hline
\end{tabular}

This table indicates that taking account of the effect of the six control variables does not hinder finding a positive and significant correlation between the level of tax evasion in emerging and developing countries and the increase in tax rates. This result is taken into account because this test gives us a p-value equal to 0.011 $<0.05$. After having verified the existence of a significant relationship between the endogenous variable and the exogenous variable, we proceeded to the verification of the meaning of this relation which is reflected from the use of the linear regression based on the OLS model.

\subsubsection{The multivariate analysis of emerging countries subsample}

In what follows, we will test the overall significance of the model, which is essentially based on the variables given in the Table of Appendix 2. Indeed, the summary table of the model (table 15) gives the following results:

Table 15. The model summary table for the 110 emerging and developing countries

\begin{tabular}{cccc}
\hline $\mathbf{R}$ & R-two & R-two ajusted & Standard error of the estimate \\
\hline 0.505 & 0.255 & 0.193 & 9.47417 \\
\hline
\end{tabular}

This table indicates that the dependence between the dependent variable and the variables used in our model has a value of 0.505 which is the value of the multiple correlation "R". The multiple coefficients of multiple determination $\mathrm{R}^{2}$ equals 0.255 indicating that the independent variable and the control variables can explain $25.5 \%$ of the variance of the phenomenon of tax evasion. For the $\mathrm{R}^{2}$ adjusted we find that the independent variable and control variables can explain the studied phenomenon at the $19.3 \%$ level, which is considered as a weakness in our model. 
For this reason, we used the Fisher's test to decide on the overall significance of the model. Hence, the use of the ANOVA table which is as follows:

Table 16. ANOVA table for the 110 emerging and developing countries

\begin{tabular}{lccccc}
\hline & Sum of squares & Ddl & $\begin{array}{c}\text { Average } \\
\text { squares }\end{array}$ & D & Sig. \\
\hline Regression & 2556.649 & 7 & 365.236 & 4.069 & 0.001 \\
Residue & 7450.073 & 83 & 89.760 & - & - \\
Total & 10006.722 & 90 & - & - & - \\
\hline
\end{tabular}

This table shows an $\mathrm{F}$ of Fisher equal to 4.069 and a p-value equal to $0.01<0.05$. This result leads to the rejection of hypothesis HO of Fisher's test which predicts that no variable can explain the dependent variable. Thus, the model contains at least one variable capable of explaining the dependent variable (TEV) and is therefore globally significant.

The development and interpretation of the model to explain the significant relationship between tax evasion and tax rate in the emerging and developing countries is based essentially on the table of coefficients (table 17) which is used to elaborate the model allowing to accept or reject our third hypothesis $\mathrm{H} 3$.

Table 17. Table of coefficients for the $\mathbf{1 1 0}$ emerging and developing countries

\begin{tabular}{llllll}
\hline \multicolumn{5}{c}{$\begin{array}{c}\text { Unstandardized } \\
\text { coefficients }\end{array}$} & $\begin{array}{l}\text { Standardized } \\
\text { coefficients }\end{array}$ \\
\hline & $\mathrm{A}$ & Standard error & Beta & $\mathrm{t}$ & Sig. \\
\hline (Constant) & 35.257 & 7.954 & & 4.432 & 0.000 \\
TR & 0.413 & 0.159 & 0.262 & 2.601 & 0.011 \\
COR & 4.694 & 2.498 & 0.195 & 1.879 & 0.064 \\
BUR & 4.665 & 2.435 & 0.199 & 1.916 & 0.059 \\
LRI & 0.653 & 0.495 & 0.142 & 1.321 & 0.190 \\
MSS & -3.195 & 1.001 & -0.334 & -3.191 & 0.002 \\
IP & 0.363 & 0.780 & 0.052 & 0.466 & 0.643 \\
ARS & -2.106 & 1.465 & -0.155 & -1.438 & 0.154 \\
\hline
\end{tabular}

The model related to the previewed table can be presented as follows:

\section{$T E V=35.257+0.413 T R+4.694 C O R+4.665 B U R+0.653 L R I-3.195 M S S+0.363 I P-$ $2.106 A R S+\varepsilon$}

From the results obtained, the tax rate in emerging and developing countries shows a positive and significant relationship with the level of tax evasion since the pvalue is equal to $0.011<0.05$ and $t$ Student is $2.601>1.96$. This indicates that (TR) 
has an effect on (TEV). Consequently, we can confirm our third hypothesis H3 the existence of a positive and significant relationship between the tax rate and the degree of evasion in emerging and developing countries. These results demonstrate that emerging and developing countries suffer from a high level of tax evasion compared to developed ones. Even worse, we notice that an increase in tax rates significantly influences the level of tax evasion in emerging and developing countries. Such a result confirms the principle that "rates cut down the totals" can be adapted to this group of countries.

In addition, we note that this phenomenon becomes more intense because of the non-development of the economic environment of the emerging and developing countries. Finally, it is worth noting that this phenomenon will have a remarkable impact on the revenues of the government of the emerging countries as they will be threatened by a continuous increase in tax rates aiming at improving their resources. However, such an increase will have a totally different effect as taxpayers and businesses will move to parallel markets to avoid tax burdens.

Such findings lead us to think of the importance of tax regime reforms that further promote tax fairness.

This was affirmed by Aim et al. (1991) who considered that developing countries suffer from the fiscal erosion that is due to the different types of tax evasion. These authors find based on the study of Jamaica's tax data, that the difference in taxation between the different sectors of activity as well as the different social classes may be among the causes of tax evasion in emerging and developing countries. Furthermore, they emphasize the importance of tax reforms that should improve the efficiency of the tax administration in terms of taxpayers' data collection as well as the training of its staff.

\section{Conclusion}

The present work aimed at studying the different factors that may affect the phenomenon of tax evasion. Indeed, the idea of our research was inspired essentially from the famous postulate in the field of research in taxation which states that "rates cut down the totals" explained by the Laffer curve. Which is why we were interested in studying the relationship between tax evasion and tax rates. Then, through a study based on the economic characteristics of several countries, we found that the increase in corporate tax rates remains a decisive factor in the phenomenon of tax evasion, mainly in emerging and developing countries; however, for developed countries we found no significant results justifying the link between tax evasion and high corporate tax rates. For this reason and through the presentation of previous research works, we have emphasized the importance of corporate tax rates which have been considered as the main source of the tax 
burden and therefore as the essential reason for tax evasion. We found that the increase in tax rates in most cases represented a positive and significant relationship with the level of tax evasion. It must be said that based on the literature review on the relationship between tax rates and tax evasion we were able to present and test three research hypotheses, which was dealing with this relationship in different countries while taking on consideration the two other assumptions which take into consideration the specific characteristics of developed countries and those of emerging and developing countries.

Our findings confirm the first and the third hypotheses of our research but do not confirm the second one. In fact, these results indicated that for a sample of 143 countries there is a positive and significant relationship between the level of tax evasion and the increase in corporate tax rates. This relationship was confirmed for emerging and developing countries, reflecting the difficulties facing the tax administrations of these countries. However, we did not find a significant relationship for developed countries, which indicates the importance of focusing on other factors to determine the sources of tax evasion in this type of economies. Like any research work, our work has some limitations, of which we can essentially cite the difference between the years in which data were collected. In addition, we can mention the missing observations during the introduction of the control variables. Our results highlight the need for a future work to study the importance of information technologies in tax administrations as well as the possible strategic orientations that can be used to fight the phenomenon of tax evasion.

\section{References}

Alm, J., Bahl, R., \& Murray, M. N. (1993) "Audit selection and income tax underreporting in the tax compliance game", Journal of Development Economics, vol. 42: 1-33.

Alm, J., Bahl, R., \& Murray, M. N. (1991) "Tax base erosion in developing countries", Economic Development and Cultural Change, vol. 39, no. 4: 849-872

Alstadsæter, A., Johannesen, N. \& Zucman, G. (2019) "Tax evasion and inequality", American Economic Review, vol. 109, no. 6: 2073-2103

Allingham, M. G., \& Sandmo, A. (1972) "Income tax evasion: a theoretical analysis", Journal of Public Economics, vol. 1, no 3-4: 323-338

Alstadsæter, A., \& Jacob, M. (2013) "The effect of awareness and incentives on tax evasion", CESifo

Working Paper Series, no. 4369

Anderson, P. (1977) "Tax evasion and labor supply", Scandinavian Journal of Economics, vol. 79: 375-83 
Artadi, V., \& Sala-i-Martin, X. (2004) “The global competitiveness index”, Global Competitiveness Report, World Economic Forum 2004

Auriol, E., \& Warlters, M. (2005) "Taxation base in developing countries", Journal of Public Economics", vol. 89: 625-646.

Beleau, A. (2013) "Theorie de la taxation optimale et politique de stabilisation : une incompatibilité theorique?", HAL (2013)

Bernasconi, M.\& Zanardi, A. (2004) "Tax evasion, tax rates and reference dependence", FinanzArchiv, vol. 60: 422-445

Bernasconi, M., Corazzini, L., \& Seri, R. (2011) "Tax evasion: Does fiscal pressure matter? Lessons from the behavioral economics", Journal of Economic Psychology, vol. 40: 103-118

Buehn, A., \& Schneider, F. (2007) "Shadow economies and corruption all over the world: Revised estimates for 120 countries", Economic; The Open-Access, Open-Assessment E-Journal, vol. 1, no. 9: 1-66

Célimène, F., Dufrénot, G., Mophou, G., \& N'Guérékata, G. (2016) “Tax evasion, tax corruption and stochastic growth", Economic Modelling, vol. 52, Part. A: $251-258$

Chiarini, B., Marzano, E., \& Schneider, F. (2008) "Tax rates and tax evasion: An empirical analysis of the structural aspects and long-run characteristics in Italy", IZA Discussion, no. 3447 (April 2008)

Clotfelter, C. (1983) "Tax evasion and tax rates: An analysis of individual returns", The Review of Economics and Statistics, vol. 65: 363-373

Cowell, F.A. (1985) "Tax evasion with labor income", Journal of Public Economics, vol. 26: 19-35

Cowell, F.A.\& Gordon, J. (1988) "Unwillingness to pay: tax evasion and public good provision", Journal of Public Economics, vol. 36: 305-321.

Cox, D. (1984) "Raising revenue in the underground economy", National Tax Journal, vol 37: 283-288

Crane, S \& Nourzad, F. (1987) "On the treatment of income tax rates in empirical analysis of tax evasion", Kyklos, vol. 40: 338-348

Dell'Anno, R. (2007) "The shadow economy in Portugal: an analysis with the MIMIC approach", Journal of Applied Economics, vol. 10: 253-277

Dell'Anno, R. \& Solomon, O.H. (2008) "Shadow economy and unemployment rate in USA: Is there a structural relationship? An empirical analysis", Applied Economics, vol. 40: 2537-2555

Desai, M. A., \& Dharmapala, D. (2004) Corporate tax avoidance and high powered incentives", Economics Working Papers, Paper 200409

Desai, M. A., Dyck, A., \& Zingales, L. (2006) "Theft and taxes", Journal of Financial Economics, vol. 84: 591-623

Djankov, S., McLiesh, C., \& Shleifer, A. (2006) "Private credit in 129 countries", Journal of Financial Economics, vol. 84, no. 2: 299-329

Dubouis, L. (1964) "La théorie de l'abus de droit et la jurisprudence administrative", Revue Internationale de Droit Comparé, vol. 16, no. 1: 231-233 
Djankov, S., La Porta, R., López-de-Silanes, F.\& Shleifer, A. (2002) "The regulation of entry", Quarterly Journal of Economics, vol.117: 1-37

Elffers, H. \& Hessing, D.J. (1997) "Influencing the prospects of tax evasion", Journal of Economic Psychology, vol. 18: 289-304

Elgin, C. \& Oztunali, O. (2012) "Shadow economies around the world: model based estimates", Bogazici University Department of Economics Working Papers, vol. 5: 1-48

Fuest, C., Maffini, G., \& Riedel, N. (2012) "What determines corporate tax payments in developing countries? Evidence from firm panel data", XXIV conference, Società italiana di economia pubblica, Pavia

Feige, E.L. \& Cebula, R. (2011) "America's underground economy: measuring the size, growth and determinants of income tax evasion in the U.S", MPRA Paper, no. 29672

Fisman, R. \& Wei, S.J. (2004) "Tax rates and tax evasion: evidence from "missing imports" in China", Journal of Political Economy, vol. 112, no. 2: 471-496

Frey, B. S., \& Weck-Hanneman, H. (1984) "The hidden economy as an unobserved variable", European Economic Review, vol. 26, no.1: 33-53

Friedman, E., Johnson, S., Kaufmann, D., \& Zoido-Lobaton, P. (2000) "Dodging the grabbing hand: the determinants of unofficial activity in 69 countries", Journal of Public Economics, vol. 76: 459-493

Franzoni, L.A. (1998) "Tax evasion and tax compliance", working paper available on SSRN

Frank, M. M., Lynch, L. J., \& Rego, S. O. (2009) "Tax reporting aggressiveness and its relation to aggressive financial reporting", The Accounting Review, vol. 84 , no. 2 : 467-496

Goswami, O., Sanyal, A., \& Gang, I. N. (1991) "Taxes, corruption, and bribes: A model of Indian public finance", Markets in developing countries: Parallel, fragmented, and black, vol. 201, no. 213: 252-253

Graetz, M., Reinganum, J.\& Wilde, L.L. (1986) "The tax compliance game: toward an interactive theory of law enforcement", Journal of Law, Economics, and Organization, vol. 2: 1-32

Haw, I.M.,Hu, B., Hwang, L.S.,\& Wu, W.(2004) "Ultimate ownership, income management, and legal and extra-legal institutions", Journal of Accounting Research, vol. 42 (2004): 423-462

Jaafar, A., \& Thornton, J. (2015) "Tax havens and effective tax rates: An analysis of private versus public european firms", The International Journal of Accounting, vol.50, no.4: 435-457

Johnson, S., Kaufmann, D., \& Zoido-Lobaton, P. (1998) "Regulatory discretion and the unofficial economy", American Economic Review, Papers and Proceedings, vol. 88, no. 2: 387-392

Johannesen, N., Tørsløv, T., \& Wier, L. (2016) “Are less developed countries more exposed to multinational tax avoidance? Method and evidence from microdata", UNU-WIDER Working Paper 2016, no. 10 
Kamdar, N. (1995) "Information reporting and tax compliance: An investigation using individual TCMP Data", Atlantic Economic Journal, vol. 23: 278292

Khlif, H., Guidara, A., \& Hussainey, K. (2016) "Sustainability level, corruption and tax evasion: a cross-country analysis", Journal of Financial Crime, vol. 23 , no. 2 : $328-348$

Koskela, E. (1983) "A note on progression, penalty schemes, and tax evasion", Journal of Public Economics, vol. 22: 127-133

La Porta, R., Lopez-de-Silanes, F., Shleifer, A.\& Vishny, R. (1998) "Law and finance", Journal of Political Economy", vol. 106, no. 6: 1113-1155

Mirrlees, J. A. (1971) "An exploration in the theory of optimum income taxation" The Review of Economic Studies, vol. 38, no. 2: 175-208

Monteiro, J., \& Assunção, J. J. (2006) "Outgoing the shadows: Estimating the impact of bureaucracy simplification and tax cut on formality and investment", Pontifícia Universidáde Católica, Department of Economics, Rio de Janeiro

Musgrave R.A. (1959) "The theory of public finance", The Economic Journal, vol. 69 , no. $276: 766-770$

Pencavel, J. (1979) "A note on income tax evasion, labor supply, and nonlinear tax schedules", Journal of Public Economics, vol. 12: 115-124

Picur, R. D., \& Riahi-Belkaoui, A. (2006) "The impact of bureaucracy, corruption and tax compliance", Review of Accounting and Finance, vol. 5, no. 2: 174-180.

Pommerehne, W. W., \& Weck-Hannemann, H. (1996) "Tax rates, tax administration and income tax evasion in Switzerland", Public Choice, vol. 88: $161-170$

Poterba, J. (1987) "Tax evasion and capital gains taxation", American Economic Review, vol. 77: 234-239

Rablen, M.D. (2010) "A reference-dependent model of tax evasion and exchange Equity", Public Finance Review, vol 38: 282-305

Rajkumar, A. S \& Swaroop, V. (2008) "Public spending and outcomes: Does governance matter?", Journal of Development Economics, vol. 86: 96-111

Reinganum, J. F., \& Wilde, L. L. (1985) "Income tax compliance in a principal agent framework", Journal of Public Economics, vol. 26: 1-18

Richardson, G. (2006) "Determinants of tax evasion: A cross-country investigation", Journal of International Accounting, Auditing and Taxation, vol. 15 , no. 2: $150-169$

Sandmo, A. (2005) "The theory of tax evasion: A retrospective view", National Tax Journal, vol. 58, no. 4: 643-663

Sanyal, A., Gang, I. N., \& Goswami, O. (2000) "Corruption, tax evasion and the Laffer curve", Public Choice, vol. 105, no. 1/2 (2000): 61-78

Slemrod, J. (1985) "An empirical test of tax evasion", Review of Economics and Statistics, vol. 67: 232-238

Slemrod, J. (2017) “Tax compliance and enforcement”, University of Michigan 
Slemrod, J. (2007) "Cheating ourselves: the economics of tax evasion" Journal of Economic Perspectives, vol. 21, no. 1: 25-48

Slemrod, J., \& Yitzhaki, S. (2002) "Tax avoidance,evasion,and administration", Handbook of Public Economics, vol.3: 1423-1470

Schneider, F., Buehn, A., \& Montenegro, C. E. (2010) "New estimates for the shadow economies all over the World", International Economic Journal, vol. 24 , no. 4: 443-461

Schwab, K. \& Sala-i-Martin, X. (2015) "The global competitiveness report 20102011", Geneva: World Economic Forum

Tversky, A., \& Kahneman, D. (1992) "Advances in prospect theory: Cumulative representation of uncertainty", Journal of Risk and Uncertainty, vol. 5, no. 4: 297-323

Vácha, P. (2014) "Challenges in auditing income taxes in the IFRS environment: The Czech Republic case", European Financial and Accounting Journal, vol. 9 , no. 4: 45-58

Wintrobe, R., \& Gërxhani, K. (2004) "Tax evasion and trust: A comparative analysis", Proceedings of the Annual Meeting of the European Public Choice Society

Wysocki, P. D. (2004) "Discussion of ultimate ownership, income management, and legal and extra-legal institutions", Journal of Accounting Research, vol. 42 , no. 2: 463-474

Yitzhaki. S. (1974) "A note on income tax evasion: A theoretical analysis", Journal of Public Economics, vol. 3: 201-202 
Appendix1: Corporate tax rate of 162 countries

\begin{tabular}{|c|c|c|c|c|c|}
\hline No & Countries & Tax rate & No & Countries & Tax rate \\
\hline 1 & Albania & 15 & 82 & Kyrgyz Republic & 10 \\
\hline 2 & Algeria & 23 & 83 & Lao PDR & 24 \\
\hline 3 & Angola & 30 & 84 & Latvia & 15 \\
\hline 4 & Argentina & 35 & 85 & Lebanon & 15 \\
\hline 5 & Armenia & 20 & 86 & Lesotho & 10 \\
\hline 6 & Australia & 30 & 87 & Liberia & 25 \\
\hline 7 & Austria & 25 & 88 & Libya & 20 \\
\hline 8 & Azerbaijan & 20 & 89 & Lithuania & 15 \\
\hline 9 & Bahamas, & 0 & 90 & Luxembourg & 29,22 \\
\hline 10 & Bahrain & 0 & 91 & Macao,China & 12 \\
\hline 11 & Bangladesh & 27,5 & 92 & Macedonia & 10 \\
\hline 12 & Belarus & 18 & 93 & Madagascar & 20 \\
\hline 13 & Belgium & 33,99 & 94 & Malawi & 30 \\
\hline 14 & Belize & 25 & 95 & Malaysia & 25 \\
\hline 15 & Benin & 30 & 96 & Maldives & 15 \\
\hline 16 & Bhutan & 30 & 97 & Mali & 30 \\
\hline 17 & Bolivia & 25 & 98 & Malta & 35 \\
\hline 18 & Bosnia \& Herzgovina & 10 & 99 & Mauritania & 25 \\
\hline 19 & Botswana & 22 & 100 & Mauritius & 15 \\
\hline 20 & Brazil & 34 & 101 & Mexico & 30 \\
\hline 21 & Brunei Darussalam & 18,5 & 102 & Moldova & 12 \\
\hline 22 & Bulgaria & 10 & 103 & Mongolia & 17,5 \\
\hline 23 & Burkina Faso & 27,5 & 104 & Morocco & 30 \\
\hline 24 & Burundi & 30 & 105 & Mozambique & 32 \\
\hline 25 & Cambodia & 20 & 106 & Myanmar & 25 \\
\hline 26 & Cameroon & 33 & 107 & Namibia & 33 \\
\hline 27 & Canada & 26,5 & 108 & Nepal & 20 \\
\hline 28 & Cape Verde & 25 & 109 & Netherlands & 25 \\
\hline 29 & Central African Republic & 30 & 110 & New Zealand & 28 \\
\hline 30 & Chad & 40 & 111 & Nicaragua & 30 \\
\hline 31 & Chile & 22,5 & 112 & Niger & 30 \\
\hline 32 & China & 25 & 113 & Nigeria & 30 \\
\hline 33 & Colombia & 25 & 114 & Norway & 27 \\
\hline 34 & Comoros & 35 & 115 & Oman & 12 \\
\hline
\end{tabular}




\begin{tabular}{|c|c|c|c|c|c|}
\hline No & Countries & Tax rate & No & Countries & Tax rate \\
\hline 35 & Congo,Dem,Rep, & 35 & 116 & Pakistan & 33 \\
\hline 36 & Congo,Rep, & 30 & 117 & Panama & 25 \\
\hline 37 & Costa Rica & 30 & 118 & Papua New Guinea & 30 \\
\hline 38 & Côte d'Ivoire & 25 & 119 & Paraguay & 10 \\
\hline 39 & Croatia & 20 & 120 & Peru & 28 \\
\hline 40 & Cyprus & 12,5 & 121 & Philippines & 30 \\
\hline 41 & Czech Republic & 19 & 122 & Poland & 19 \\
\hline 42 & Denmark & 23,5 & 123 & Portugal & 21 \\
\hline 43 & Dominican Republic & 27 & 124 & Quatar & 10 \\
\hline 44 & Ecuador & 22 & 125 & Romania & 16 \\
\hline 45 & Egypt,Arab Rep, & 22,5 & 126 & Russian Federation & 20 \\
\hline 46 & El Salvador & 30 & 127 & Rwanda & 30 \\
\hline 47 & Equatorial Guinea & 35 & 128 & Saudi Arabia & 20 \\
\hline 48 & Eritrea & 30 & 129 & Senegal & 30 \\
\hline 49 & Estonia & 20 & 130 & Sierra Leone & 30 \\
\hline 50 & Ethiopia & 30 & 131 & Singapore & 17 \\
\hline 51 & Fiji & 20 & 132 & Slovak Republic & 22 \\
\hline 52 & Finland & 20 & 133 & Slovenia & 17 \\
\hline 53 & France & 33,33 & 134 & Solomon Islands & 30 \\
\hline 54 & Gabon & 30 & 135 & South Africa & 28 \\
\hline 55 & Gambia,The & 31 & 136 & Spain & 28 \\
\hline 56 & Georgia & 15 & 137 & Sri Lanka & 28 \\
\hline 57 & Germany & 29,65 & 138 & Sudan & 35 \\
\hline 58 & Ghana & 25 & 139 & Suriname & 36 \\
\hline 59 & Greece & 29 & 140 & Swaziland & 27,5 \\
\hline 60 & Guatemala & 25 & 141 & Sweden & 22 \\
\hline 61 & Guinea & 35 & 142 & Switzerland & 17,92 \\
\hline 62 & Guinea-Bissau & 25 & 143 & Syrian Arab Republic & 22 \\
\hline 63 & Guyana & 30 & 144 & Taiwan & 17 \\
\hline 64 & Haiti & 30 & 145 & Tajikistan & 15 \\
\hline 65 & Honduras & 30 & 146 & Tanzania & 30 \\
\hline 66 & Hong Kong,China & 16,5 & 147 & Thailand & 20 \\
\hline 67 & Hungary & 19 & 148 & Togo & 29 \\
\hline 68 & Iceland & 20 & 149 & Trinidad and Tobago & 25 \\
\hline 69 & India & 34,61 & 150 & Tunisia & 25 \\
\hline
\end{tabular}

Vol. 19, No. 2 
The impact of tax rates on tax evasion: A macroeconomic study

\begin{tabular}{llllll}
\hline No & \multicolumn{1}{c}{ Countries } & Tax rate & No & Countries & Tax rate \\
\hline 70 & Indonesia & 25 & 151 & Turkey & 20 \\
71 & Iran,Islamic Rep, & 25 & 152 & Uganda & 30 \\
72 & Ireland & 12,5 & 153 & Ukraine & 18 \\
73 & Israel & 26,5 & 154 & United Arab Emirates & 55 \\
74 & Italy & 31,4 & 155 & United Kingdom & 20 \\
75 & Jamaica & 25 & 156 & United States & 40 \\
76 & Japan & 33,06 & 157 & Uruguay & 25 \\
77 & Jordan & 20 & 158 & Venezuela,RB & 34 \\
78 & Kazakhstan & 20 & 159 & Vietnam & 22 \\
79 & Kenya & 30 & 160 & Yemen,Rep, & 20 \\
80 & Korea,Rep, & 24,2 & 161 & Zambia & 35 \\
81 & Kuwait & 15 & 162 & Zimbabwe & 25,75 \\
\hline
\end{tabular}

Appendix 2: Description and measures of variables

\begin{tabular}{|c|c|c|}
\hline Variables & Description & Measures \\
\hline TEV & $\begin{array}{l}\text { The intensity of tax evasion } \\
\text { according to Shneider et al } \\
(2010)\end{array}$ & $\begin{array}{l}\text { Average size of parallel markets } \\
\text { estimated between } 1999 \text { and } 2007 \text { as } \\
\text { a percentage of GDP }\end{array}$ \\
\hline TR & $\begin{array}{l}\text { Tax rate in } 2015 \text { according to } \\
\text { KPMG and the World Bank }\end{array}$ & Percentage \\
\hline COR & $\begin{array}{c}\text { Importance of corruption in a } \\
\text { country }\end{array}$ & $\begin{array}{l}=1 \text { if it has one of the top } 5 \text { problem } \\
\text { factors according to GCR of the } \\
\text { WEF } \&=0 \text { if no }\end{array}$ \\
\hline BUR & $\begin{array}{l}\text { Importance of bureaucracy in a } \\
\text { country }\end{array}$ & $\begin{array}{l}=1 \text { if it has one of the top } 5 \text { problem } \\
\text { factors according to GCR of the } \\
\text { WEF \& }=0 \text { if no }\end{array}$ \\
\hline IP & $\begin{array}{l}\text { The level of investor protection } \\
\text { in } 2013\end{array}$ & scale from 0 to 10 \\
\hline $\begin{array}{l}\text { LRI (legal } \\
\text { right index) }\end{array}$ & $\begin{array}{l}\text { the level of legal protection of the } \\
\text { rights of stakeholders }\end{array}$ & scale from 0 to 10 \\
\hline $\begin{array}{l}\text { MSS (market } \\
\text { size score) }\end{array}$ & $\begin{array}{l}\text { the size of the markets (local / } \\
\text { foreign /\% export to GDP) }\end{array}$ & scale from 1 to 7 \\
\hline ARS & $\begin{array}{l}\text { the quality of auditing and } \\
\text { reporting standards }\end{array}$ & scale from 1 to 7 \\
\hline
\end{tabular}

